\title{
Analysis of protein profile of tomato root infected with Fusarium oxysporum f. sp lycopersici
}

\author{
T.D. Silva ${ }^{1,3}$, C.M.A. Almeida ${ }^{1}$, C.B. Malafaia ${ }^{1,3}$, L.M.S. Oliveira ${ }^{1}$, \\ M.V. Silva ${ }^{2}$ and M.T.S. Correia ${ }^{2}$ \\ ${ }^{1}$ Programa de Pós-Graduação em Ciências Biológicas, \\ Centro de Ciências Biológicas, Universidade Federal de Pernambuco, \\ Recife, PE, Brasil \\ ${ }^{2}$ Departamento de Bioquímica, Universidade Federal de Pernambuco, \\ Recife, PE Brasil \\ ${ }^{3}$ Central Analítica, Centro de Tecnologias Estratégicas do Nordeste, \\ Recife, PE, Brasil \\ Corresponding author: T.D. Silva \\ E-mail: diegotulio1@gmail.com
}

Genet. Mol. Res. 16 (2): gmr16027209

Received November 30, 2016

Accepted March 14, 2017

Published May 25, 2017

DOI http://dx.doi.org/10.4238/gmr16027209

Copyright $(C 2017$ The Authors. This is an open-access article distributed under the terms of the Creative Commons Attribution ShareAlike (CC BY-SA) 4.0 License.

ABSTRACT. Fusarium wilt caused by Fusarium oxysporum f. sp lycopersici (Fol) is one of the main diseases affecting tomatoes. The BHRS 2,3 genotype of tomato is, however, resistant to this disease. A proteomic approach was used to understand the defense mechanisms of this genotype using the tomato root, the first tissue that interacts with the fungus, as a target. Protein was extracted and separated by two-dimensional electrophoresis followed by staining with Coomassie brilliant blue. The proteins were identified by MALDI-TOF/TOF mass spectrometry. A total of 22 proteins were identified, 21 of which showed differential expression with 12 proteins being upregulated and nine being downregulated. Plants responded to the pathogen with increased expression of pathogenesis-related proteins. We noted the

Genetics and Molecular Research 16 (2): gmr16027209 
induction of proteins involved in hypersensitivity reaction and other defense mechanisms. The expression of proteins of primary metabolism related to energy production, however, decreased, as did the expression of two proteins related to defense against abiotic stress. These results demonstrate the presence of important mechanisms for defense against Fol in the tomato genotype BHRS 2,3.

Key words: Solanum lycopersicum; Biotic stress; Fusarium wilt; Proteomics

\section{INTRODUCTION}

The fusarium wilt, caused by the soil fungus Fusarium oxysporum f. sp lycopersici (Fol), is one of the most aggressive diseases affecting the tomato crop. The disease causes great damage, especially in sensitive cultivars and in environments where the air and soil temperature are high, as in tropical countries during the warm seasons (Agrios, 2005). The classical strategies, such as the use of fungicides and crop rotation have not been efficient due to the resistant spores that remain viable for several years, and because of the impact of pesticide residues on human health. Selective breeding has contributed to the emergence of more aggressive new breeds of pathogen. Therefore, it is necessary to develop new and efficient control strategies that do not compromise the environmental safety (Mandal et al., 2009). Resistant cultivars developed by gene transfer appear to be one of the most promising options to combat the disease (Dean et al., 2012). However, resistance to diseases involves a complex mechanism involving recognition of virulence determinants by plant receptors followed by specific signal transduction pathways leading to the production and release of reactive oxygen species, phytoalexins, pathogenesisrelated (PR) proteins, in addition to programmed cell death (Torres et al., 2006). Studies on inductors show that resistance to Fol may be related to salicylic acid (Mandal et al., 2009). However, little is known about the molecular relationships among the metabolic pathways, such as recognition, signaling, and plant response, in addition to components not directly related to infection.

Root is the first site to detect and fight soil fungus infections such as Fol. Consequently, understanding the molecular mechanisms happening in this tissue is necessary to improve resistance to the pathogen. Differential proteomics, essentially finds out proteins with different expression levels among different samples caused by a specific factor, is an important part of global proteomic studies. An overview of protein expression can be obtained at high resolution by separating proteins by dimensional (2-DE) electrophoresis combined with peptide identification via tandem mass spectrometry (MS/MS; Manaa et al., 2011; Que et al., 2011). This proteomic approach has become a powerful tool for studying plant development in general and its use has significantly increased in the studies of various stresses, both biotic and abiotic in origin (Faurobert et al., 2007).

The present study analyzed the protein profile of the BHRS 2,3 tomato cultivar, known for its resistance to Fol, with an aim of identifying those with differential expression, using the 2-DE proteomic technologies associated with matrix assisted laser desorption ionization, tandem time of flight mass spectrometer (MALDI-TOF-TOF/MS), which are associated with the defense against the fungus.

Genetics and Molecular Research 16 (2): gmr16027209 


\section{MATERIAL AND METHODS}

\section{Tomato line and $F$. oxysporum isolate}

The wild-type BHRS 2,3 tomato genotype, resistant to fusarium wilt but having no economic value, was used in the present study. The material was procured from the Vegetable Improvement Program of Instituto Agronômico de Pernambuco, Recife, Pernambuco, Brazil. The race 2 isolate of Fol was obtained from the Mycology Collection of the Department of Phytopathology from Universidade Federal Rural de Pernambuco, Brazil.

\section{Experimental design and protein extraction}

Seeds were sown in 128-celled Styrofoam trays filled with sterile substrate Plantmax ${ }^{\circledR}$. Plants, with first-two pairs of true leaves fully open (about 21 days after planting), were removed from the cells with a gentle jet of water to preserve their root integrity. The apical sector (about $2 \mathrm{~cm}$ ) of the root was removed and then dipped for $20 \mathrm{~min}$ in a spore suspension containing approximately $2 \times 10^{6}$ conidia/mL, cultured in potato dextrose broth for seven days at $28^{\circ} \mathrm{C}$, under continuous light. A group of plants was mock-inoculated with water and used as control. After inoculation, the plantlets were transplanted to $1.5 \mathrm{~kg}$ plastic pots containing sterile soil and maintained in a greenhouse. The experimental plots contained three pots, with four plants each, in a randomized block design. Plants were collected 1, 2, 4, and 6 days after the inoculation and were stored at $-80^{\circ} \mathrm{C}$.

Roots $(1000 \mathrm{mg})$ were ground in ice-cold extraction buffer containing $8 \mathrm{M}$ urea, $4 \%$ CHAPS, $10 \mathrm{mM}$ phenylmethylsulfonylfluoride, and $7 \mathrm{mM}$ dithiothreitol (DTT). The mixture was centrifuged at $12,000 \mathrm{~g}$ for $20 \mathrm{~min}$, and the supernatant collected. Proteins were precipitated with five-volumes ice-cold trichloroacetic acid-acetone $(10 \%$ trichloroacetic acid in $100 \%$ acetone) at $-20^{\circ} \mathrm{C}$ for $6 \mathrm{~h}$ and then collected by centrifugation at $20,000 \mathrm{~g}$ for $20 \mathrm{~min}$. The precipitated protein was centrifuged at $20,000 \mathrm{~g}$ for $20 \mathrm{~min}$, washed three times in $10 \mathrm{~mL}$ ice-cold acetone, with vigorous disruption of the pellet with a glass rod between each wash, and air-dried. The proteins obtained were dissolved in a lysis buffer ( $8 \mathrm{M}$ urea, $4 \%$ CHAPS, 7 $\mathrm{mM} \mathrm{DTT}$, and $2 \%$ pharmalyte $4-7$ ) at room temperature and stored in aliquots at $-80^{\circ} \mathrm{C}$, until they were used.

\section{2-DE and image analysis}

Protein samples $(600 \mu \mathrm{g})$ mixed with $250 \mu \mathrm{L}$ rehydration buffer (containing $8 \mathrm{M}$ urea, $2 \% \mathrm{w} / \mathrm{v}$ CHAPS, $20 \mathrm{mM}$ DTT, and $0.5 \%$ IPG buffer; GE Healthcare, Piscataway, NJ, USA), and $0.002 \%$ bromophenol blue were loaded onto IPG strips $(13 \mathrm{~cm})$, with a linear $\mathrm{pH}$ range 4-7 (GE Healthcare, Piscataway, NJ, USA), after a brief sonication and centrifugation. Isoelectric focusing was performed in an Ettan ${ }^{\mathrm{TM}}$ IPGphor ${ }^{\mathrm{TM}} 3$ isoelectric focusing system (GE Healthcare, Uppsala, Sweden) following the manufacturer protocol. Before electrophoresing in the second dimension, the IPG strips were equilibrated for $15 \mathrm{~min}$, first in a buffer containing $6 \mathrm{M}$ urea, $30 \%(\mathrm{w} / \mathrm{v})$ glycerol, $2 \%(\mathrm{w} / \mathrm{v}) \mathrm{SDS}$, and $100 \mathrm{mM}$ Tris-HCl, $\mathrm{pH} 8.8$, supplemented with $100 \mathrm{mM}$ DTT and subsequently for $15 \mathrm{~min}$ in the same buffer with $0.25 \mathrm{M}$ iodoacetamide added. The equilibrated IPG strips were transferred onto $12.5 \%$ SDS polyacrylamide gels and electrophoresed on an Ettan SE 600 Ruby electrophoresis unit (GE Healthcare, Uppsala,

Genetics and Molecular Research 16 (2): gmr16027209 
Sweden). The separated proteins were visualized by staining the gels with Coomassie brilliant blue (CBB)-R250 (Candiano et al., 2004). Images of the CBB-stained gels were acquired at 300-dpi resolution and 16-bit pixel depth, and subsequently analyzed with the ImageMaster 2D Platinum 6.0 (GE Healthcare, Piscataway, NJ, USA) software according to the protocols provided by the manufacturer. The intensity of each spot was normalized by total valid spot intensity. Protein spots were considered differentially expressed if the intensity changed more than two times in the different stages.

\section{MALDI-TOF-TOF/MS}

In-gel digestion of proteins was performed as described by Shevchenko et al. (2006), with minor modifications. Trypsin was used at a concentration $25 \mathrm{ng} / \mu \mathrm{L}$ and the in-gel reduction and alkylation steps were omitted. The peptides, thus generated, were dissolved in $10 \mu \mathrm{L} 0.1 \%$ trifluoracetic acid (TFA). A saturated solution of alpha-cyano-4-hydroxycinnamic acid (CHCA; $4 \mathrm{mg} / \mathrm{mL}$ ) in 50\% acetonitrile and $0.3 \%$ TFA was mixed with equal amounts of sample, spotted on an Anchor Chip 800/384 target plate (Bruker Daltonics, Germany), and dried in laminar airflow for recrystallization. For MS calibration, $0.5 \mu \mathrm{L}$ peptide calibration standard (Bruker Daltonics, Germany) was spotted on the target with $0.8 \mu \mathrm{L} \mathrm{CHCA}$ matrix and recrystallized, as described above. The samples were analyzed on a MALDI TOF-TOF/ MS Ultraflex III (Bruker Daltonics, Germany) used in the reflectron mode. The peptides with a signal-to-noise ratio above 100 were further analyzed by MS/MS using the LIFT technology embedded in the Ultraflex MS; on an average, ten MS/MS spectra were measured for each protein digest leading to the identification of 2-10 peptides. Data processing was realized using the Flex analysis and BioTools software packages (Bruker Daltonics, Germany).

Data analysis was performed using the BioTools 3.0 software, using MASCOT (Matrix Science, London, UK) as a search engine. The parameters were set as follows: database was NCBI (nr); retrieval genera were set as all; data acquisition method was set as combined; maximum missing cut site allowed was set as 1 ; enzyme was set as trypsin. The quality error scope was set as follows: PMF 0.3D; MS/MS 0.4D.

\section{RESULTS AND DISCUSSION}

The time-points for sample collection were chosen based on previous experiments (Malafaia et al., 2013). About 1400-1800 $\mu \mathrm{g}$ protein was extracted from $1 \mathrm{~g}$ root tissue of the treated plants. The resolution of approximately $600 \mu \mathrm{g}$ protein loaded on each gel showed an average of 450-550 spots with $\mathrm{pI}$ ranging between 4 and 7 and the molecular mass ranging between 90 and $10 \mathrm{kDa}$ (Figure 1). The 2-DE comparative analysis carried out among the treatments achieved 65\% (22 of 34 spots) successful identifications of the proteins. The changes in protein expression, in the plants before and after the pathogen inoculation, were evaluated by comparing the protein profiles. The assessment performed in triplicate revealed 21 differentially expressed spots (Figure 2). Of the identified proteins, the expression of 11 was increased whereas that of 10 proteins was decreased. However, calreticulin, which was present at a high concentration, did not show a differential expression (Table 1). Among the upregulated proteins, two were of unknown function, while among those with known functions, one was involved in primary metabolism, seven in defense against stresses, and one in signaling. Among the identified proteins showing a decreased expression, five were related

Genetics and Molecular Research 16 (2): gmr16027209 
to primary metabolism, one to abiotic stress, one to recovery from oxidative stress, and two were of unknown function. The proteins with no differential expression were associated with both primary metabolism and defense.

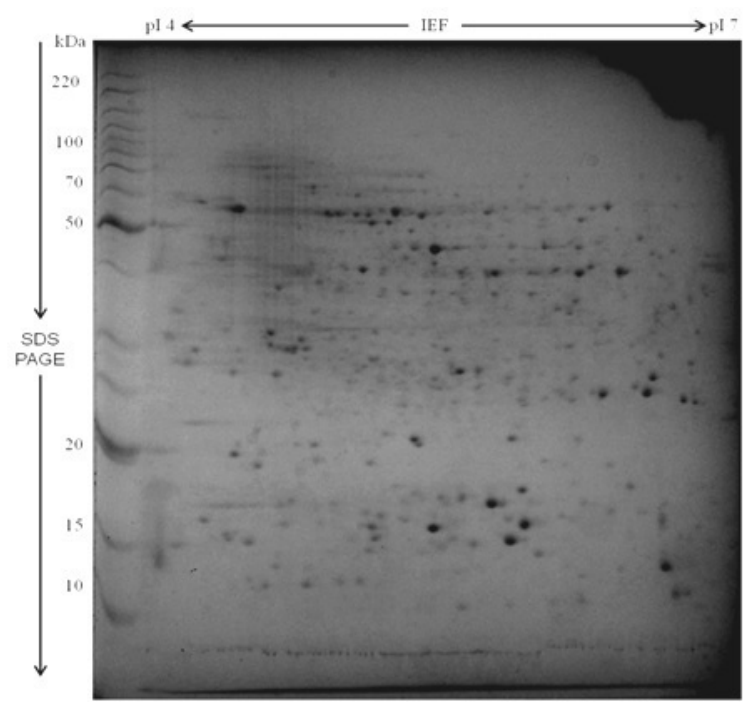

Figure 1. Overview of the proteome of tomato roots infected with Fusarium oxysporum f. sp lycopersici, separated by two-dimensional electrophoresis. The proteome was resolved through IEF/SDS-PAGE (12.5\%) using a linear pI range 4-7 and molecular mass range 10-220 $\mathrm{kDa}$.

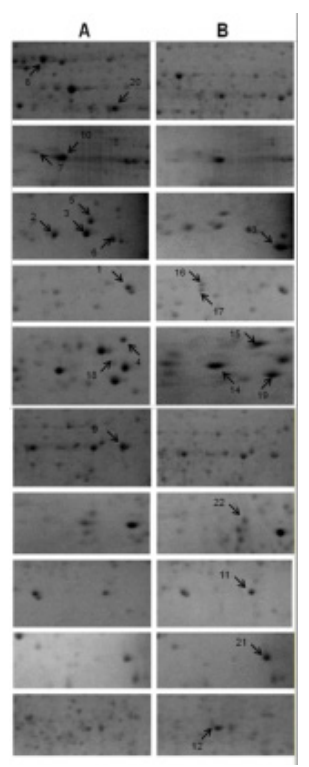

Figure 2. Expanded regions of the 2-D gels showing spots of proteins that were differentially expressed. Panel A shows the spots in the samples from the healthy plant. Panel B shows the spots in the samples from plants inoculated with Fusarium oxysporum. The spot numbers indicated by arrows are according to the numbers used in Table 1.

Genetics and Molecular Research 16 (2): gmr16027209 
Table 1. List of root proteins that were differentially regulated in the BHRS 2,3 tomato genotype after challenge with Fusarium oxysporum.

\begin{tabular}{|c|c|c|c|c|c|c|c|}
\hline Spot ${ }^{\mathrm{a}}$ & Identity ${ }^{\mathrm{b}}$ & Organism $^{\mathrm{c}}$ & Accession $^{\mathrm{d}}$ & Score $^{\mathrm{e}}$ & $\mathrm{pI}^{\mathrm{f}}$ & $\mathrm{Mr}^{\mathrm{f}}$ & Regulation $^{\mathrm{g}}$ \\
\hline 1 & ATP synthase D chain, mitochondrial, putative & Solanum demissum & gi|48209968 & 48 & 6.63 & 19.37 & Down \\
\hline 2 & Glutathione $S$-transferase, class-phi & Solanum commersonii & gi|2290782 & 58 & 5.81 & 23.8 & Down \\
\hline 3 & Glutathione $S$-transferase, class-phi & Solanum commersonii & gi 2290782 & 58 & 5.81 & 23.8 & Down \\
\hline 4 & 17.8-kDa class I heat shock protein & Solanum lycopersicum & gi 232273 & 154 & 5.84 & 17.75 & Down \\
\hline 5 & Triose phosphate isomerase cytosolic isoform & Solanum chacoense & gi|38112662 & 93 & 5.73 & 27.25 & Down \\
\hline 6 & Putative protein & Arabidopsis thaliana & gi|3269288 & 97 & 6.3 & 22.35 & Down \\
\hline 7 & Uncharacterized protein At5g39570 & Vitis vinifera & gi|225452887 & 67 & 4.71 & 43.01 & Down \\
\hline 8 & ATP synthase subunit beta, mitochondrial; Flags: Precursor & Nicotiana plumbaginifolia & gi $\mid 114421$ & 62 & 5.95 & 59.93 & Down \\
\hline 9 & Mitochondrial malate dehydrogenase & Solanum lycopersicum & gi|350536645 & 83 & 8.87 & 36.35 & Down \\
\hline 10 & Calreticulin & Arabidopsis thaliana & gi|1009712 & 71 & 4.37 & 46.7 & - \\
\hline 11 & Predicted protein & Micromonas sp RCC299 & gi 255084065 & 74 & 9.26 & 33.04 & Up \\
\hline 12 & Endochitinase & Solanum chilense & gi|767827 & 95 & 6.21 & 27.53 & Up \\
\hline 13 & Pathogenesis-related protein (PR-5 protein) & Solanum lycopersicum & gi 7414370 & 43 & 5.76 & 27.52 & Up \\
\hline 14 & RNA-binding glycine-rich protein-1a & Nicotiana sylvestris & gi 469070 & 58 & 5.58 & 15.6 & Up \\
\hline 15 & Glycine-rich protein & Solanum lycopersicum & gi|19322 & 146 & 9.98 & 7.3 & Up \\
\hline 16 & Lemir & Solanum lycopersicum & gi 2654440 & 77 & 4.83 & 23.27 & Up \\
\hline 17 & Lemir & Solanum lycopersicum & gi|2654440 & 77 & 4.84 & 23.28 & Up \\
\hline 18 & 40S ribosomal protein $\mathrm{S} 12$ & Hordeum vulgare & gi|12229949 & 105 & 5.35 & 15.62 & Up \\
\hline 19 & Superoxide dismutase $[\mathrm{Cu}-\mathrm{Zn}]$ & Solanum lycopersicum & gi 350537277 & 89 & 5.83 & 15.4 & Up \\
\hline 20 & Unknown & Glycine $\max$ & gi|255638991 & 62 & 7.51 & 36.38 & Up \\
\hline 21 & Nucleoside diphosphate kinase & Solanum lycopersicum & gi 350535074 & 135 & 7.04 & 15.07 & Up \\
\hline 22 & Actin & Solanum tuberosum & gi|3219759 & 40.7 & 5.38 & 41.9 & Up \\
\hline
\end{tabular}

${ }^{a}$ Number allocated according to the numbers used in Figure 1. ${ }^{b}$ Identification of protein annotated by mass spectrometry. ${ }^{\mathrm{c} P l a n t}$ species from which protein was annotated. ${ }^{\mathrm{d} A c c e s s i o n}$ number to the database (nrNCBI). ${ }^{\mathrm{e}} \mathrm{MASCOT}$ score. ${ }^{\mathrm{f}}$ Theoretical molecular weight and isoelectric point computed from the calculation tool $\mathrm{Mr} / \mathrm{pI}$ from ExPASy. ${ }^{\mathrm{g}}$ Note of the regulation type suffered by the protein.

Several strategies are employed by plants to perceive and resist stresses induced by pathogens (Kundu et al., 2011). The genotype of BHRS 2,3 tomato has no relevant agronomic characteristics; however, it is resistant to diseases such as fusarium wilt, unlike other genotypes of economic importance. Therefore, studies on defense mechanisms that confer characteristic resistance to this genotype are important for breeding resistant cultivars. Root is the first tissue to interact with the fusarium pathogen; therefore, it was used in this study to identify proteins involved in the defense against this phytopathogen. The proteome of tomato roots has been discussed in previous reports ( $\mathrm{Li}$ et al., 2008), but such studies have not analyzed the influence of fungal infection.

There was an increase in the plant defense-related proteins after infection with the pathogen. In addition, there was an increased expression of chitinase (PR-3), PR-5 protein, LeMir (Lycopersicon esculentum miraculin), nucleoside diphosphate kinase (NDPK), RNA binding glycine rich protein (GRP), superoxide dismutase (Cu-Zn SOD), and actin. Usually, there is an increase in the expression of PR proteins, along with fortification of other responses, when plants are challenged by pathogens. The PR proteins (spots 12 and 13) were present in the unchallenged plants at low concentration, but their expression was observed to increase under pathogen attack or abiotic stress (Dahal et al., 2009). Plant chitinases, which are mostly endochitinases, are reported to participate in the protection, due to their fungal cell wall degrading potential that limits the invasion and growth of pathogen into the host (Ahmed et al., 2012). The PR-5 proteins, also known as thaumatin-like protein due to their similarity with this protein, have been observed to participate in the defense against many pathogens and other abiotic stressors (Ren et al., 2011). Although the mechanisms of action for this protein group have not yet been elucidated, their performance in fighting fungal infections, for example, by inhibition of spore germination and mycelial growth, has been described (Tachi et al., 2009). The induction of PR proteins is considered an activation marker of the basal defense in plants (Dahal et al., 2009).

Genetics and Molecular Research 16 (2): gmr16027209 
Hypersensitive reaction (HR) is one of the most efficient forms of plant defense against pathogens (Karrer et al., 1998). LeMir (spots 16 and 17) was secreted and concentrated in roots in response to infestation by nematodes, suggesting its involvement in plant defense against these organisms (Brenner et al., 1998). Moreover, overexpression of this protein was observed in lesions caused by hypersensitive response in tomato plants, demonstrating that LeMir plays an important role in regulating a variety of HR types (Xu et al., 2012). Another HR mechanism is the release of reactive oxygen species (ROS; de Souza et al., 2011). Some ROS, such as $\mathrm{H}_{2} \mathrm{O}_{2}$, were confirmed as large signaling molecules, promoting greater tolerance of plants to pathogens (Kim et al., 2007). The enzyme SOD (spot 19) is one of the proteins responsible for the antioxidative response, transforming superoxide into hydrogen peroxide (Madanala et al., 2011). The use of SOD to control the ROS concentration in cells is a strategy to activate the signaling of defense pathways such as those involving mitogen-activated protein kinases, which seems to be central in the cellular response to multiple stressors (Apel and Hirt, 2004).

Actin (spot 22) is an essential component in all living beings, responsible for the cytoskeleton formation in several cells of organisms (Franklin-Tong and Gourlay, 2008). In plants, the actin cytoskeleton is also used as a sensor for stress monitoring and is a part of the mechanisms that trigger the HR and programmed cell death (PCD). The actin filaments are reorganized, and accumulate and line up near the infection site, thus allowing isolation of the area where there is PCD (Franklin-Tong and Gourlay, 2008). Although, there is evidence for the actin-ROS interaction during the HR, the fact has not yet been proven (Franklin-Tong and Gourlay, 2008). Thus, increased expression of two LeMir isoforms against the Fol infection as well as that of an enzyme related to ROS and actin, processes related to HR and PDC, is indicative of the resistance of the BHRS 2,3 genotype to this disease.

NDPK (spot 21) is a protein responsible for cellular organization, regulating the nucleotide groups in the cells (Kihara et al., 2011). It has been reported to be involved in signal transduction in plants. In potatoes, NDPK was associated with increased tolerance to multiple stresses (Tang et al., 2008). In rice, there was an increased NDPK1 expression in response to infection by the pathogen, Xanthomonas oryzae pv oryzae, in addition to elicitors, such as salicylic acid and jasmonic acid, showing a defensive role of NDPK against microorganisms (Cho et al., 2004).

GRP (spots 14 and 15) are involved in various pathways and have a structural function, providing elasticity to the cell wall. They are also involved in post-transcriptional regulation of genes in response to stress (Wang et al., 2012). Increased GRP expression has been reported in response to salt stress, cold, heat, injury, and viral and fungal infections (Kwak et al., 2005). However, their mechanisms of action have not been fully elucidated (Wang et al., 2012). The presence of two isoforms of this protein, with increased expression in response to Fol, corroborates the results of these studies, suggesting that GRP has a role in plant defense.

A decrease in the expression of some proteins associated with primary metabolism (spots 1, 5, 8, and 9) was observed in response to the fungus. ATP synthase is a key protein responsible for energy production (Rexroth et al., 2012). The ROS production, resulting from the infection, directly affects the efficiency of this enzyme due to oxidation of its tryptophan residues, resulting in degradation of the enzyme oxidized by specific proteases (Rexroth et al., 2012). The decreased expression of proteins, such as malate dehydrogenase and triose phosphate isomerase, linked to energy cycles (Hadži-Tašković Šukalović et al., 2011), is related to resource reduction for the fungus and limits its development. Calreticulin is a protein that participates in both the regulation of plant development and protection against abiotic and

Genetics and Molecular Research 16 (2): gmr16027209 
biotic stresses (An et al., 2011). With respect to biotic stresses, calreticulins were found to play a role in defense against viruses (Shen et al., 2010). Thus, the presence of this protein in the BHRS 2,3 genotype, even without increased expression, shows its role in different routes, by which it can interact.

However, some proteins related to stress defense showed decreased expression (spots 2, 3, and 4). Glutathione $S$-transferase (GST) is responsible for maintaining the redox state of plants; it combines electrophilic xenobiotics with glutathione, thus reducing their toxicity (Sytykiewicz, 2011). Another defense-related protein that also showed decreased expression upon Fol infection was the class I heat shock resistance (HSP) protein. This group acts as chaperone, linking other proteins, stabilizing unstable structures, and facilitating the modeling of inactive proteins. They are expressed rapidly and abundantly under various stress conditions (Bondino et al., 2012). Decreased expression of HSP and GST proteins during infection is an unusual event. However, the decrease of GST may be related to the fact that during the hypersensitivity reaction there was a need for some ROS being present in the tissue, but this fact needs to be proven.

The present study revealed proteome modifications in the BHRS 2,3 genotype upon the Fol challenge that could contribute to the understanding of this plant-pathogen interaction. The differential expression of the proteins related to defense or stress and primary metabolism in response to the pathogen supports their fundamental role in the plant defense mechanisms. However, further studies are warranted to find other mechanisms and to identify the initiation of processes such as perception of the infection and signaling.

\section{Conflicts of interest}

The authors declare no conflict of interest.

\section{ACKNOWLEDGMENTS}

Research supported by Instituto Agronômico de Pernambuco (IPA), Fundação de Amparo à Pesquisa do Estado de Pernambuco (FACEPE), Banco do Nordeste (BNB), and Conselho Nacional de Desenvolvimento Científico e Tecnológico (CNPq).

\section{REFERENCES}

Agrios GN (2005). Plant pathology. 5th edn. Academic Press, St. Louis.

Ahmed NU, Park JI, Seo MS, Kumar TS, et al. (2012). Identification and expression analysis of chitinase genes related to biotic stress resistance in Brassica. Mol. Biol. Rep. 39: 3649-3657. http://dx.doi.org/10.1007/s11033-011-1139-x

An YQ, Lin RM, Wang FT, Feng J, et al. (2011). Molecular cloning of a new wheat calreticulin gene TaCRT1 and expression analysis in plant defense responses and abiotic stress resistance. Genet. Mol. Res. 10: 3576-3585. http:// dx.doi.org/10.4238/2011.November.10.1

Apel K and Hirt H (2004). Reactive oxygen species: metabolism, oxidative stress, and signal transduction. Annu. Rev. Plant Biol. 55: 373-399. http://dx.doi.org/10.1146/annurev.arplant.55.031903.141701

Bondino HG, Valle EM and Ten Have A (2012). Evolution and functional diversification of the small heat shock protein/ $\alpha-$ crystallin family in higher plants. Planta 235: 1299-1313. http://dx.doi.org/10.1007/s00425-011-1575-9

Brenner ED, Lambert KN, Kaloshian I and Williamson VM (1998). Characterization of LeMir, a root-knot nematodeinduced gene in tomato with an encoded product secreted from the root. Plant Physiol. 118: 237-247. http://dx.doi. org/10.1104/pp.118.1.237

Candiano G, Bruschi M, Musante L, Santucci L, et al. (2004). Blue silver: a very sensitive colloidal Coomassie G-250

Genetics and Molecular Research 16 (2): gmr16027209 
staining for proteome analysis. Electrophoresis 25: 1327-1333. http://dx.doi.org/10.1002/elps.200305844

Cho SM, Shin SH, Kim KS, Kim YC, et al. (2004). Enhanced expression of a gene encoding a nucleoside diphosphate kinase 1 (OsNDPK1) in rice plants upon infection with bacterial pathogens. Mol. Cells 18: 390-395.

Dahal D, Heintz D, Van Dorsselaer A, Braun HP, et al. (2009). Pathogenesis and stress related, as well as metabolic proteins are regulated in tomato stems infected with Ralstonia solanacearum. Plant Physiol. Biochem. 47: 838-846. http://dx.doi.org/10.1016/j.plaphy.2009.05.001

de Souza WR, Vessecchi R, Dorta DJ, Uyemura SA, et al. (2011). Characterization of Rubus fruticosus mitochondria and salicylic acid inhibition of reactive oxygen species generation at Complex III/Q cycle: potential implications for hypersensitive response in plants. J. Bioenerg. Biomembr. 43: 237-246. http://dx.doi.org/10.1007/s10863-011-9357-4

Dean R, Van Kan JA, Pretorius ZA, Hammond-Kosack KE, et al. (2012). The Top 10 fungal pathogens in molecular plant pathology. Mol. Plant Pathol. 13: 414-430. http://dx.doi.org/10.1111/j.1364-3703.2011.00783.x

Faurobert M, Mihr C, Bertin N, Pawlowski T, et al. (2007). Major proteome variations associated with cherry tomato pericarp development and ripening. Plant Physiol. 143: 1327-1346. http://dx.doi.org/10.1104/pp.106.092817

Franklin-Tong VE and Gourlay CW (2008). A role for actin in regulating apoptosis/programmed cell death: evidence spanning yeast, plants and animals. Biochem. J. 413: 389-404. http://dx.doi.org/10.1042/BJ20080320

Hadži-Tašković Šukalović V, Vuletić M, Marković K and Vučinić Z (2011). Cell wall-associated malate dehydrogenase activity from maize roots. Plant Sci. 181: 465-470. http://dx.doi.org/10.1016/j.plantsci.2011.07.007

Karrer EE, Beachy RN and Holt CA (1998). Cloning of tobacco genes that elicit the hypersensitive response. Plant Mol. Biol. 36: 681-690. http://dx.doi.org/10.1023/A:1005949304445

Kihara A, Saburi W, Wakuta S, Kim MH, et al. (2011). Physiological and biochemical characterization of three nucleoside diphosphate kinase isozymes from rice (Oryza sativa L.). Biosci. Biotechnol. Biochem. 75: 1740-1745. http://dx.doi. org $/ 10.1271 / \mathrm{bbb} .110285$

Kim MS, Kim HS, Kim HN, Kim YS, et al. (2007). Growth and tuberization of transgenic potato plants expressing sense and antisense sequences of $\mathrm{Cu} / \mathrm{Zn}$ superoxide dismutase from lily chloroplasts. J. Plant Biol. 50: 490-495. http:// dx.doi.org/10.1007/BF03030688

Kundu S, Chakraborty D and Pal A (2011). Proteomic analysis of salicylic acid induced resistance to Mungbean Yellow Mosaic India Virus in Vigna mungo. J. Proteomics 74: 337-349. http://dx.doi.org/10.1016/j.jprot.2010.11.012

Kwak KJ, Kim YO and Kang H (2005). Characterization of transgenic Arabidopsis plants overexpressing GR-RBP4 under high salinity, dehydration, or cold stress. J. Exp. Bot. 56: 3007-3016. http://dx.doi.org/10.1093/jxb/eri298

Li J, Wu XD, Hao ST, Wang XJ, et al. (2008). Proteomic response to iron deficiency in tomato root. Proteomics 8: 22992311. http://dx.doi.org/10.1002/pmic.200700942

Madanala R, Gupta V, Deeba F, Upadhyay SK, et al. (2011). A highly stable Cu/Zn superoxide dismutase from Withania somnifera plant: gene cloning, expression and characterization of the recombinant protein. Biotechnol. Lett. 33: 2057-2063. http://dx.doi.org/10.1007/s10529-011-0670-0

Malafaia CB, Silva TD, Amaral DOJ, Almeida CMA, et al. (2013). Evaluation of the resistance and differential induction of chitinases in tomato in response to inoculation with Fusarium oxysporum f. sp. lycopersici. Plant Physiol. Pathol 1: 3 .

Manaa A, Ben Ahmed H, Valot B, Bouchet JP, et al. (2011). Salt and genotype impact on plant physiology and root proteome variations in tomato. J. Exp. Bot. 62: 2797-2813. http://dx.doi.org/10.1093/jxb/erq460

Mandal S, Mallick N and Mitra A (2009). Salicylic acid-induced resistance to Fusarium oxysporum f. sp. lycopersici in tomato. Plant Physiol. Biochem. 47: 642-649. http://dx.doi.org/10.1016/j.plaphy.2009.03.001

Que Y, Xu L, Lin J, Ruan M, et al. (2011). Differential protein expression in sugarcane during sugarcane-Sporisorium scitamineum interaction revealed by 2-DE and MALDI-TOF-TOF/MS. Comp. Funct. Genomics 2011: 989016 http:// dx.doi.org/10.1155/2011/989016.

Ren X, Kong Q, Wang P, Jiang F, et al. (2011). Molecular cloning of a PR-5 like protein gene from cherry tomato and analysis of the response of this gene to abiotic stresses. Mol. Biol. Rep. 38: 801-807. http://dx.doi.org/10.1007/ $\underline{\text { s11033-010-0169-0 }}$

Rexroth S, Poetsch A, Rögner M, Hamann A, et al. (2012). Reactive oxygen species target specific tryptophan site in the mitochondrial ATP synthase. Biochim. Biophys. Acta 1817: 381-387. http://dx.doi.org/10.1016/j.bbabio.2011.11.006

Shen W, Yan P, Gao L, Pan X, et al. (2010). Helper component-proteinase (HC-Pro) protein of Papaya ringspot virus interacts with papaya calreticulin. Mol. Plant Pathol. 11: 335-346. http://dx.doi.org/10.1111/j.1364-3703.2009.00606.x

Shevchenko A, Tomas H, Havlis J, Olsen JV, et al. (2006). In-gel digestion for mass spectrometric characterization of proteins and proteomes. Nat. Protoc. 1: 2856-2860. http://dx.doi.org/10.1038/nprot.2006.468

Sytykiewicz H (2011). Expression patterns of glutathione transferase gene (GstI) in maize seedlings under juglone-induced oxidative stress. Int. J. Mol. Sci. 12: 7982-7995. http://dx.doi.org/10.3390/ijms12117982

Genetics and Molecular Research 16 (2): gmr16027209 
Tachi H, Fukuda-Yamada K, Kojima T, Shiraiwa M, et al. (2009). Molecular characterization of a novel soybean gene encoding a neutral PR-5 protein induced by high-salt stress. Plant Physiol. Biochem. 47: 73-79. http://dx.doi. org/10.1016/j.plaphy.2008.09.012

Tang L, Kim MD, Yang KS, Kwon SY, et al. (2008). Enhanced tolerance of transgenic potato plants overexpressing nucleoside diphosphate kinase 2 against multiple environmental stresses. Transgenic Res. 17: 705-715. http://dx.doi. org $/ 10.1007 / \mathrm{s} 11248-007-9155-2$

Torres MA, Jones JD and Dangl JL (2006). Reactive oxygen species signaling in response to pathogens. Plant Physiol. 141: 373-378. http://dx.doi.org/10.1104/pp.106.079467

Wang C, Zhang DW, Wang YC, Zheng L, et al. (2012). A glycine-rich RNA-binding protein can mediate physiological responses in transgenic plants under salt stress. Mol. Biol. Rep. 39: 1047-1053. http://dx.doi.org/10.1007/s11033011-0830-2

Xu QF, Cheng WS, Li SS, Li W, et al. (2012). Identification of genes required for Cf-dependent hypersensitive cell death by combined proteomic and RNA interfering analyses. J. Exp. Bot. 63: 2421-2435. http://dx.doi.org/10.1093/jxb/ err397

Genetics and Molecular Research 16 (2): gmr16027209 